\title{
Fiscal Federalism for Emerging Economies: Lessons from Switzerland?
}

\author{
Ivan Baron Adamovich \\ University of Fribourg \\ Gerald Hosp \\ University of Fribourg
}

\begin{abstract}
Switzerland is one of the most non-centralized countries in the world. A growing literature is examining the economic effects of tax competition between the 26 Swiss cantons. Despite the relative success of Swiss federalism, most federal countries follow the principles of coordinated rather than competitive federalism. We identify the institutional preconditions for well-functioning competitive federalism in Switzerland. The second part deals with the applicability of the Swiss experience for emerging economies in Latin America. The analysis recognizes that most institutions identified to be crucial in the Swiss case are missing in Latin America. This leads to the policy conclusion that competitive federalism can only produce its positive effects under certain institutional circumstances. These circumstances are often not considered when introducing lax competition in emerging economies.
\end{abstract}

There is growing evidence that the organization of the state matters. The effects of fiscal federalism and decentralization are not only discussed with respect to the European Union but also to the emerging economies all over the world.' Wallace E. Oates puts it this way: "In the developing world, we. . . see widespread interest in fiscal decentralization with the objective of breaking the grip of central planning that, in the view of many, has failed to bring these nations onto a path of self-sustaining growth." ${ }^{2}$

The key question is: How should the functions of the state be distributed to different orders or levels of government in order to achieve an optimal division of public duties? However, no consensus about the optimal level of decentralization has emerged up to now, neither theoretically nor empirically. In particular, there is a lack of econometric research comparing states with different degrees of decentralization. Although studies of this kind could improve our understanding of the overall effects of

AUTHORS'NOTE: We would like to thank Peter Beez, Reiner Eichenberger ${ }_{\xi}$ Georg v. Graevenitz, Bruno Jeitziner, Henner Kleinewefers and three anonymous referees and the participants of the "Federalism" session at the Sixth Annual Meeting of the Latin American and Caribbean Economic Association (LACEA), 18-20 October 2001 in Montevideo, for helpful comments.

'See, for example, Kiichiro Fukasaku and Luiz R. De Mello Jr., eds., La décentratisation budgetaire dans les économies émergentes: problèmes de gestion des affaires publiques (Paris: Centre de Développement de 1'Organisation de Coopération et de Développement Économiques, 1999) and Vito Tanzi, Pitfalls on the Road to Fistal Decentralization (Washington, DC: Carnegie Endowment Working Paper Nr. 19, 2001). 1120.

${ }^{2}$ Wallace E. Oates, "An Essay on Fiscal Federalism," Journal of Economic Literature 37 (September 1999):

(-) Publius: The Journal of Federalism 33:1 (Winter 2003) 
decentralization, the operationalization of federalism remains the key problem. Consequently, it seems reasonable to analyze the experience of single decentralized countries in order to learn more about the conditions and effects of fiscal federalism. As one of the most non-centralized countries, Switzerland appears to be a natural object for this kind of research.

For a better understanding, we first provide some details about the Swiss fiscal constitution. Switzerland consists of three orders of government: the federal government, 26 cantons, and nearly 3,000 local government units. Nine cantons account for less than 100,000 inhabitants, the smallest canton having only 15,000 people. Cantons and local jurisdictions are provided with considerable fiscal competences. ${ }^{3}$ Thus, almost 75 percent of the total tax burden on personal and corporate income consists of cantonal and local taxes. Swiss municipalities can levy a surcharge on cantonal direct taxes and raise their own property taxes. Personal income taxes vary remarkably across and within the cantons. ${ }^{4}$ As an example, a family with two children that earns a gross income of CHF 150,000 has to pay only CHF 10,095 of cantonal and local taxes in the city of Zug, but CHF 24,255 in Basel. These cities are located in two different cantons and within a distance of 125 kilometers. ${ }^{5}$ The federal government relies mainly on indirect (proportional) taxes, specific consumption taxes, a general sales tax, and small but highly progressive income taxes. Differences between jurisdictions are smoothed out by federal, intercantonal, and intracantonal grants and transfers. The contributions to this mechanism are determined by the fiscal capacity of each canton.

As the above facts indicate, the Swiss fiscal system is thoroughly noncentralized. In the last ten years, this has led many scholars to analyze the economic effects of tax competition in Switzerland. ${ }^{6}$ According to the literature, there is considerable empirical evidence for generally positive effects of fiscal federalism in Switzerland. Building on this, scholars have recently started to study the institutional preconditions for this system. They stress the fact that fiscal federalism does not necessarily work under all

'The Swiss Constitution explicitly enumerates all the competences of the federal authorities. Cantons and municipalities are provided with a constitutionally guaranteed autonomy in all other issues. Changes of the Constitution are difficult because they are submitted to a referendum.

"See Lars P. Feld and Friedrich Schneider, "State and Local Taxation," International Encyclopedia of Social and Behavioral Science, Vol. 12 Economics, eds. Neil J. Smelser and Paul B. Baltes (Oxford: Elsevier, 2001).

${ }^{5}$ Swiss Federal Tax Administration (Eidgenössisches Finanzdepartement), Index der Finanzkraft der Kantone für die Jahre 2000 und 2001, 12 November 2001; http://www.efv.admin.ch/finanzen/d/oefffina/ pdf_dateien/fk00.pdf

${ }^{6}$ See Hansjōrg Blöchliger and Renẻ L. Frey, "Der schweizerische Fōderalismus-Ein Modell für den institutionellen Aufbau der Europäischen Union?" Aussenwirtschaft 47 (Heft IV 1992): 515-548; Bruno S. Frey and Iris Bohnet, "Democracy by Competition-Referenda and Federalism in Switzerland," Publius: The Journal of Federalism 23 (Spring 1993): 71-81; Reiner Eichenberger, "The Benefits of Federalism and the Risk of Overcentralization," Kyklos 47 (3 1994): 403-420; Gebhard Kirchgässner and Werner W. Pommerehne, "Die Entwicklung der öffentlichen Finanzen in föderativen Systemen," Staatsaufgaben, ed. Dieter Grimm (Baden-Baden: Nomos, 1994), pp. 149-176; Werner W. Pommerehne, Gebhard Kirchgässner et al., "Tax Harmonization and Tax Competition at State-Local Levels-Lessons from Switzerland," Developments in Local Government Finance, eds. Giancarlo Pola, George France, and Rosella Levaggi (Cheltenham, Brookfield: Elgar, 1996), pp. 292-330; and Lars P. Feld, "Tax competition and income redistribution: An empirical analysis for Switzerland," Public Choice 105 (1-2 2000): 125-164. 
circumstances, because institutions matter. ${ }^{7}$ Naturally, this leads us to the question: Can the Swiss experience be a model for political strategies in the emerging economies in Latin America and other regions of the world, or is the institutional framework in Switzerland so singular that the Swiss experience is of no use for political strategies in other countries? ${ }^{8}$

We will proceed as follows. The next section briefly presents the theoretical arguments for and against fiscal federalism from an economic point of view and explains the difference between competitive and coordinated federalism. The theoretical arguments are then confronted with empirical evidence from Switzerland. In a further step, an attempt is made to identify specific institutions conducive to the functioning of fiscal federalism in Switzerland. The subsequent section deals with the applicability of the Swiss experience to emerging economies in Latin America. The analysis first recognizes that most formal and informal institutions identified to be crucial for the functioning of Swiss fiscal federalism are not present in Latin America. It then examines a group of challenges for fiscal federalism in emerging economies (i.e., internal market, informal economy, and important differences in regional income and corruption). This leads to the policy conclusion that fiscal federalism can only produce positive effects under certain institutional circumstances. These circumstances are often not considered when introducing tax competition.

\section{THEORETICAL BACKGROUND}

Proponents of fiscal federalism argue that tax competition corresponds to the idea of fiscal equivalence, gives local politicians more responsibility, and leads politicians to manage their budgets more carefully and according to the preferences of their constituents. Skeptics, however, fear a race to the bottom and an inefficient production of public goods. In order to be able to offer an analytical guideline for the assessment of federal institutions, we distinguish between different kinds of fiscal federalism.

\section{The Economic Theory of Federalism Revisited}

From an economic point of view, federalism is defined as a system where jurisdictions within a nation-state have a considerable amount of tax and spending autonomy. ${ }^{9}$ This section very briefly deals with the most important

${ }^{7}$ See Michael Wohlgemuth and Ivan Baron Adamovich, Systemwettbewerb in der Schweiz-Ein Testfall für das Zusammenspiel von "Exil", "Voice" und "Loyalty" (Jena: Max-Planck-Institut zur Erforschung von Wirtschaftssystemen, 1999); Feld and Schneider, "State and Local Taxation"; and Reiner Eichenberger and Gerald Hosp, "Die institutionellen Leitplanken wirkungsvollen Föderalismus-Erfahrungen aus der Schweiz," Öhonomische Aspekte des Föderalismus, eds. Peter Pernthaler and Peter BuBjāger (Wien: Wilhelm Braumüller, 2001), pp. 87-104.

${ }^{8}$ Linked to this statement is the idea that decentralization may be similar to a superior good, which becomes more demanded when income increases. The causality seems to go the opposite way in countries which started as federations like the United States or Switzerland.

The economic theory of federalism goes back to the famous article by Charles $M$. Tiebout, "A Pure Theory of Local Government Expenditures," Joumal of Political Economy (October 1956): 415-426. For a concept of federalism more focused on direct democracy see Bruno $S$. Frey and Reiner Eichenberger, The New Democratic Federalism for Europe: Functional, Overlapping and Competing Junisdictions (Cheltenham: Elgar, 1999). 
theoretical arguments for and against fiscal federalism. As the arguments are widely known, we will just present the key elements.

The traditional economic theory of fiscal federalism is concerned with the provision of public services by the various orders of government and the assignment of the proper fiscal instruments. ${ }^{10}$ Demand for public services varies across (and within) jurisdictions. Decentralization provides incentives and possibilities for governments to generate better knowledge about the preferences of the people because they are closer to them. In turn, people are closer to governments and can thus better control the activities of politicians and bureaucrats. " According to a more recent body of literature, the positive effects of fiscal federalism are linked to the idea of a properly functioning interjurisdictional competition. This can be summarized as follows:

- In a federally organized system, citizens and capital have better possibilities for "exit" from a jurisdiction than in centralist states. Consequently, local governments are forced to be more aware of the preferences of citizens and enterprises if they want to prevent them from moving to other jurisdictions that offer better packages of taxes and public services. Some authors claim that this effect is reinforced when citizens in a jurisdiction have the right to decide about the tax burden themselves (e.g., in procedures of direct democracy).$^{12}$

- The higher intensity of interjurisdictional competition in federally organized states is said to produce incentives for innovations in the political sphere. The idea is that innovations can (and will) be tested in jurisdictions where there is demand from the constituents and where the conditions are favorable. Innovations that follow a "bottom-up" pattern are expected to be cheaper and more successful than experiments imposed "topdown." 13 This argument is based on Friedrich A. von Hayek's idea of "competition as a discovery procedure."14

Geoffrey $\mathrm{H}$. Brennan and James $\mathrm{M}$. Buchanan advance the hypothesis that the overall size of the public sector "should be smaller, ceteris paribus, the greater the extent to which taxes and expenditures are decentralized." 15

${ }^{10}$ Overviews are provided by Wallace E. Oates, Fiscal Federalism (Aldershot: Gregg Revivals, 1972) and Wallace E. Oates, "An Essay on Fiscal Federalism," Journal of Economic Literature XXXVII (September 1999): 1120-1149.

"See Bruno S. Frey and Iris Bohnet, "Democracy by Competition-Referenda and Federalism in Switzerland," Publius: The Journal of Federalism 23 (Spring 1993): 71-81.

${ }^{12}$ See Wohlgemuth and Adamovich, Systemwettbewerb in der Schweiz-Ein Testfall für das Zusammenspiel von "Exit", "Voice" und "Loyalty," and Eichenberger and Hosp, "Die institutionellen Leitplanken wirkungsvollen Fôderalismus-Erfahrungen aus der Schweiz," pp. 87-104.

13Ibid.

${ }^{14}$ See Friedrich A. von Hayek, "Competition as a Discovery Procedure," New Studies in Philosophy, Politics and Economics, ed. Friedrich A. von Hayek (Chicago: University of Chicago Press, 1978), pp. 179-190.

${ }^{15}$ Geoffrey H. Brennan and James M. Buchanan, The Power to Tax-Analytical Foundations of a Fiscal Constitution (Cambridge: Cambridge University Press, 1980), p. 185 
Nevertheless, studies by Oates find that there seems to be no clear evidence for this claim. Also, as Philip J. Grossman shows, decentralization can reduce government size but tax collusion may weaken this effect. ${ }^{16}$ Ernesto Stein even observes for Latin America that decentralized governments tend to be larger. As he points out, one interpretation can be that citizens are more satisfied in smaller units and therefore demand more public services. ${ }^{17}$

As to the broader relationship between fiscal federalism and economic performance, there is not much empirical evidence. However, a World Bank study by Jeff Huther and Anwar Shah finds a statistically significant and positive correlation between fiscal federalism and political governance quality in most cases. Of course, this does not tell us anything about the direction in which the influence goes; that is, fiscal decentralization could also be something like a luxury good. ${ }^{18}$

The skeptical view of fiscal federalism can be summarized in three main arguments:

- Due to the low cost of mobility between the jurisdictions of a federal state, citizens and capital move to places with low taxes. According to critics of fiscal federalism, this generates a race to the bottom as governments are forced to lower taxes continuously until public spending cannot be financed any more. In theory, this would lead to a complete breakdown of public services. Closely linked to this scenario is the idea that fiscal federalism impedes redistribution as people with higher income tend to avoid taxes by moving to other jurisdictions with lower taxation. ${ }^{19}$

- Fiscal federalism is often advocated for ethnically and geographically divided societies. Skeptics fear that this will lead to increasing claims for more autonomy, thus endangering the unity of the federal polity. Apart from that, the division into subnational jurisdictions is expected to produce new minority problems. Thus, fiscal decentralization is said to be not only inefficient but even dangerous.

- Skeptics of fiscal federalism argue that smaller jurisdictions cannot take advantage of economies of scale. A different version of this critique claims that smaller fiscal units are too small to be able to survive economically.

${ }^{16}$ See Wallace E. Oates, "Searching for Leviathan: An Empirical Study," American Economic Review 75 (1985): 748-757; Wallace E. Oates, "Searching for Leviathan: A Reply and Some Further Reflections," American Economic Reviezu 79 (1989): 578-583; and Philip J. Grossman, "Fiscal Decentralization and Government Size: An Extension," Public Choice 62 (1989): 63-69.

${ }^{17}$ Ernesto Stein, "Fiscal Decentralization and Government Size in Latin America," Journal of Applied Economics II (2 1999): 357-391

${ }^{18}$ See Jeff Huther and Anwar Shah, A Simple Measure of Good Governance and Its Application to the Debate on the Appropriate Level of Fiscal Decentralization (Washington DC: World Bank, 1996). For an overview of other empirical studies that go in the same direction, see Oates, "An Essay on Fiscal Federalism."

${ }^{19}$ See Hans-Werner Sinn, "Tax Harmonization and Tax Competition in Europe," European Economic Review 34 (1990): 489-504; and Hans-Werner Sinn, "The Selection Principle and Market Failure in Systems Competition," Journal of Public Economics 66 (1997): 247-274 
We could not find empirical studies that affirm the theoretical arguments of the skeptics of fiscal federalism. Moreover, as we will show, Switzerland seems to contradict the critics empirically.

\section{Competitive versus Coordinated Federalism}

In the literature, multiple approaches can be found for differentiating between alternative kinds of federalism. Scholars like Robert P. Inman and Daniel L. Rubinfeld or Yingyi Qian and Barry R. Weingast, for example, evaluate different forms of federalism in terms of their impact on economic efficiency, distribution of income, political participation, and protection of individual rights and liberties. For our purpose, we contrast competitive with coordinated federalism. ${ }^{20}$

The notion of competitive federalism not only contains an aspect of mobile production factors in the sense of Charles $\mathrm{M}$. Tiebout, but is also concerned with competition as a constraint for political actors. ${ }^{21}$ First of all, it is characterized by the autonomy over taxes and public services. This primary authority of subnational governments should be combined with hard budget-constraints. According to the literature on market-preserving federalism, hard budget-constraints mean that subnational governments are unable to create and to borrow money unlimitedly. Furthermore, the national government is not willing to bail out troubled regional and local governments. Within a competitive environment, subnational governments will be punished if they underperform in comparison to other jurisdictions. Mobile resources will choose the "exit" option. Yingyi Qian and Gérard Roland even state that interjurisdictional competition leads to the endogeneous emergence of harder budget-constraints. ${ }^{22}$ Finally, competitive federalism can only persist if the national government does not have the competences to centralize taxes and public services because, otherwise, the center would gradually seize the powers from the lower jurisdictions. Charles B. Blankart has empirically shown this process for Germany between 1950 and $1995 .^{23}$ That means that centralization is only possible if all the subnational jurisdictions unanimously decide to concede the power to tax to the federal authorities. This makes attempts of cartelization to avoid competition very difficult and can be conceived of as a credible commitment by the constituent states to preserve federalism.

The main argument for coordinated federalism is the adjustment of differences between jurisdictions. However, as compared to competitive

${ }^{20}$ See Robert P. Inman and Daniel L. Rubinfeld, "Rethinking Federalism," Journal of Economic Perspectives 11 (4 1997): 43-64 and Yingyi Quian and Barry R. Weingast, "Federalism as a Commitment to Preserving Market Incentives," Journal of Economic Perspectives 11 (4 1997): 83-99.

"See Tiebout, "A Pure Theory of Local Government Expenditures," 415-426.

${ }^{22}$ See Yingyi Qian and Gérard Roland, "Federalism and the Soft Budget Constraint," American Economic Review 88 (5 1998): 1143-1162 and Quian and Weingast, "Federalism as a Commitment to Preserving Market Incentives."

${ }^{23}$ See Charles B. Blankart, "The Process of Government Centralization: A Constitutional View," Constitutional Political Economy 11 (1 2000): 27-39. 
federalism, coordinated federalism is characterized by a higher level of harmonization within the federation. Coordinating and bargaining are the driving principles of this kind of federalism. If subnational governments are not able to prevent other jurisdictions from free riding or to enforce agreements, they will try to push competences to the federal government. Blankart calls this process an attempt to build up a cartel on tax rates. ${ }^{24}$ Intergovernmental tax-sharing rules are signs for such cartels. In this context, soft budget-constraints are more probable. Because subnational governments are not completely responsible for their financial situation, federal governments have the duty to help troubled governments. From this point of view, coordinated federalism does not seem to be a sustainable institutional arrangement. Table 1 summarizes the most important differences between competitive and coordinated federalism.

Table 1

Competitive Versus Coordinated Federalism

\begin{tabular}{lcc}
\hline & $\begin{array}{c}\text { Competitive } \\
\text { Federalism }\end{array}$ & $\begin{array}{c}\text { Coordinated } \\
\text { Federalism }\end{array}$ \\
\hline Harmonization of tax bases and rates & Low & High \\
Harmonization of public services & Low & High \\
Budget constraint for lower jurisdictions & Hard & Soft \\
Tendency for centralization & Low & High \\
\hline
\end{tabular}

Obviously, our sympathy is with competitive federalism. Nevertheless, we have to stress that these two concepts of federalism describe two points on a continuum. One extreme would be complete desintegration of the federation; the other would be complete centralization. For the analysis of federalism, the important question is, which principle-competition or coordination-should be the driving force of the system.

\section{FISCAL FEDERALISM IN SWITZERLAND}

According to a considerable number of empirical studies, tax competition in Switzerland has positive effects overall. Nevertheless, it seems that the Swiss federal system is based on very specific institutional preconditions (e.g., state and local tax assignment, direct democratic elements, intergovernmental grants, and revenue sharing, but also informal institutions).

\section{Competitive Fiscal Federalism in Switzerland}

In spite of the marked federal structure, Switzerland's internal markets allow the free movement of capital, labor, goods, and services-not only in theory but (largely) also in reality. Important conditions for functioning markets (e.g., common civil and criminal laws, a common currency, or a universal infrastructure) are provided. Given that geographical distances 24Ibid., 37. 
are relatively small, the costs of mobility are a minor factor obstructing movement between jurisdictions. However, the mobility of labor may be hindered by cultural barriers because Switzerland consists of three regions differing in language and culture. In sum, as already remarked above, Switzerland bears the potential for very intense interjurisdictional competition.

Of course, it is difficult to prove empirically the positive effects of fiscal federalism enumerated in previous sections. Nevertheless, Philip J. Grossman, Panayiotis Mavros, and Robert W. Wassmer provide evidence that pressure from competing cities is an effective check on the technical efficiency of governments. ${ }^{25}$ According to Hansjörg Blöchliger and René L. Frey, in Switzerland the incentive mechanisms work as predicted by the theory; competition generates better information and incentives for politicians to produce public goods not only in better accordance to the preferences of the voters but also in a more efficient way. ${ }^{26}$ It is possible that this is an important reason why Switzerland still has the smallest government size in Europe (38.5 percent general government expenditures of GDP) after Ireland ( 31.5 percent) in spite of a strong growth of total government expenditures during the 1990s. ${ }^{27}$

An interesting feature of the Swiss fiscal system is that it largely corresponds to the guidelines proposed by Richard A. Musgrave, which sketch an optimal distribution of taxation between federal, state, and local governments. According to Musgrave, the provision of public goods should be decentralized as far as possible, while redistribution policies should stay with the national authorities. With reference to taxes, federal authorities should rely on a highly progressive income tax for redistribution reasons and on a consumption tax if subnational jurisdictions are small. Federal subunits (e.g., states or cantons) should levy income and consumption taxes (if the units are large enough) and also a natural-resource tax. Finally, municipalities should levy property taxes. ${ }^{28}$ Except for minor aspects in income and corporate taxes, Switzerland corresponds to Musgrave's model. ${ }^{29}$ Table 2 shows this in detail. Thus, the only important difference seems to be that municipalities can impose a surcharge on the cantonal individual and corporate income taxes. But, in fact, this is an important difference because it is conducive to (or even necessary for) interjurisdictional competition. Another interesting point is that the Swiss fiscal system is not

${ }^{25}$ See PhilipJ. Grossman, Panayiotis Mavros, and Robert W. Wassmer, "Public Sector Technical Efficiency in Large U.S. Cities," Journal of Urban Economics 46 (1999): 278-299.

${ }^{26}$ See Blöchliger and Frey, "Der schweizerische Föderalismus-Ein Modell für den institutionellen Aufbau der Europāischen Union?" and Gebhard Kirchgässner and Werner W. Pommerehne, "Tax Harmonization and Tax Competition in the European Union-Lessons from Switzerland," Journal of Public Economics 61 (1996): 66-82. Here, direct democracy seems to be an important factor. See section 3.2 .

${ }^{27}$ Swiss Federal Tax Administration (Eidgenössisches Finanzdepartement), Staatsquote International 12 November 2001, http://www.admin.ch/efv/finanzen/d/intvergl/intstaq.htm.

"zsee Richard A. Musgrave, "Who Should Tax, Where and What?" Tax Assignment in Federal Countries, ed. Charles E. McLure (Canberra: Centre for Research on Federal Financial Relations, 1983), pp. 2-19.

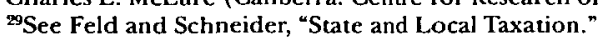


the outcome of a grand design of some mastermind but has evolved in the vertical and horizontal competition between the different jurisdictions.

Table 2

Tax Assignment

\begin{tabular}{lll}
\hline & Guidelines by Musgrave & Swiss Fiscal System \\
\hline Federal authorities & $\begin{array}{l}\text { Progressive income tax and } \\
\text { consumption tax (if lower } \\
\text { jurisdictions are small) }\end{array}$ & $\begin{array}{l}\text { Progressive income tax, } \\
\text { consumption tax (lower } \\
\text { jurisdictions are small), } \\
\text { and corporate income tax }\end{array}$ \\
States / Cantons & Residents' income tax & $\begin{array}{l}\text { Personal and corporate } \\
\text { income tax, inheritance } \\
\text { tax, and wealth tax }\end{array}$ \\
Local governments & $\begin{array}{l}\text { Property taxes and payroll } \\
\text { taxes }\end{array}$ & $\begin{array}{l}\text { Personal and corporate } \\
\text { income tax surcharge and } \\
\text { property tax }\end{array}$ \\
\hline
\end{tabular}

It is easier to deal with the expected negative effects of fiscal federalism, as the Swiss experience proves to be an empirical contradiction to all of them. First of all, a variety of studies prove that the race-to-the-bottom hypothesis is not valid for Switzerland, but that tax competition works well in producing hard budget-constraints for politicians.

- For Switzerland, the cantonal tax burden matters for the migration decisions of individuals with a relatively high income (above CHF $100,000)$. Lars P. Feld finds that persons with higher income look at taxes and infrastructure only, and not at redistribution. However, individuals with lower incomes do take redistribution into account when they migrate to another canton. ${ }^{30}$

- According to Feld, there is something like a migrational equilibrium in Switzerland. In his analysis for the years 1989 and 1990, he found that there was almost no migration between the cantons. Moreover, Feld was unable to find sound evidence regarding fiscally induced migration between Swiss cantons in the 1980s and between cities from 1986 to $1994 .{ }^{31}$ However, the share of persons with a taxable income of more than 100,000 $\mathrm{CHF}$ was 9.41 percent in the canton of Zug and 2.53 percent in the canton of Jura (average: 5.47 percent), with Zug having the lowest tax burden, Jura the highest. ${ }^{32}$ Geneva, however, proves that taxes are not the only explanatory variable for the geographic

"See Lars P. Feld, "Exit, Voice and Income Taxes-The Loyalty of Voters," European Journal of Political Economy 13 (3 1997): 455-478 and Feld, "Tax competition and income redistribution: An empirical analysis for Switzerland, ${ }^{n} 125-164$

${ }^{31}$ See Feld, "Tax competition and income redistribution: An empirical analysis for Switzerland," 134.

${ }^{32}$ See Feld, "Exit, Voice and Income Taxes-The Loyalty of Voters," 455-478. 
distribution of individuals with high income; the percentage of people with high taxable income is important in Geneva, although it has a relatively high tax burden.

- Tax competition in Switzerland has not led to a convergence of the tax burden in the different cantons. ${ }^{33}$ Taking the overall tax burden as a benchmark (index: 100), the average deviation for the 26 cantons was 13.5 points in $1985,14.8$ in 1990 , and 15.3 in 1996. Also, the spread between the cantons with the highest and the lowest tax burden remained more or less unchanged. In 1985, it was 134 index points for the highest and 67 for the lowest tax burden; in 1990, 146 and 58; in 1996, 136 and 55. ${ }^{34}$

- The Swiss welfare state has not collapsed. An important share of the redistribution takes place in the cantonal and municipal arenas. $^{35}$ In fact, the proportion of transfers and subsidies in relation to Swiss GDP has significantly grown since the 1980 s. In 1980, 13.4 percent of the GDP was redistributed; in 1990, 16.0 percent; and in $1995,18.3$ percent. $^{36}$ Although Switzerland has the smallest government size in Europe, the amount of transfers and subventions is substantial and has not declined.

The other two arguments-"federalism has disintegrating consequences" and "federal subunits are too small"-can also be dismissed for the Swiss case. As to the first argument, the Swiss federation has been a very successful example of the peaceful coexistence of four different cultures for at least 150 years (since the constitution of 1848). In addition, Reiner Eichenberger and Gerald Hosp claim that a successful federal system does not only build on ethnically different regions but also on the more intense competition between jurisdictions with more similar cultural backgrounds. They argue that the strengths of the Swiss federal system stem from the very fact that there is an especially intense competition between the cantons that have the same language and culture..$^{37}$

The second argument stating that federal subunits are too small to be efficient is only valid if the jurisdictions do not have the incentives to

${ }^{33}$ Ravi Kanbur and Michael Keen show that tax competition does not unavoidably lead to convergence in tax rates. Differences in size has a large impact on the strategies of countries. Smaller countries charge a lower tax rate in a noncooperative equilibrium than larger countries. See Ravi Kanbur and Michael Keen, "Jeux Sans Frontières: Tax Competition and Tax Coordination When Countries Differ in Size," American Economic Review 83 (4 1993): 877-892.

${ }^{34}$ See Wohlgemuth and Adamovich, Systemwettberverb in der Schweiz-Ein Testfall für das Zusammenspiel von "Exil", "Voice" und "Loyally." The canton of Zug has been pursuing a radical strategy of low taxes since the mid 1960s. Up to now, no other canton has felt obliged to do the same. Zug has been the canton with the lowest taxes since then.

${ }^{35}$ See Gebhard Kirchgässner and Werner W. Pommerehne, "Tax Harmonization and Tax Competition in the European Union-Lessons from Switzerland," 66-82 and Lars P. Feld and Friedrich Schneider, "State and Local Taxation." The same phenomenon can be observed in the United States.

scSee James D. Gwartney and Robert A. Lawson, Economic Freedom of the World (Bonn: Liberales Institut, 1997), p. 178.

${ }^{37}$ See Eichenberger and Hosp, "Die institutionellen Leitplanken wirkungsvollen FöderalismusErfahrungen aus der Schweiz, ${ }^{, ~ 87-104 . ~}$ 
cooperate on issues concerning more than one federal subunit. These incentives are mainly linked to the economic openness and fiscal autonomy of jurisdictions. Finally, the economic success of small cantons (and even municipalities) clearly contradicts the argument that small units cannot survive economically. ${ }^{38}$

In general, the Swiss experience seems to provide some evidence in favor of the claimed positive effects of fiscal or competitive federalism. At the same time, the negative effects can be mitigated or even averted. In any case, it can be argued that an at least potentially intense interjurisdictional (tax) competition does not necessarily lead to the collapse of the welfare system or to an inability of the state to provide the basic public services. ${ }^{39}$

\section{Institutions Matter}

If, as we have seen above, fiscal federalism works in Switzerland, does this automatically mean that it works everywhere else, or is the institutional framework in Switzerland so unique that the Swiss experience cannot be taken as an example for other countries or regions? To be able to deal with these questions, formal and informal institutions in Switzerland considered to be conducive to the functioning of fiscal federalism have to be analyzed. We have identified four institutions that seem to have especially positive effects in this respect: (1) a system of intergovernmental redistribution; (2) a compensation mechanism for transfers paid to immigrants from other cantons; (3) extensive elements of direct democracy giving citizens rights of participation in local decisionmaking; and (4) "loyalty" as a consequence of specific investments.

As we have emphasized, competition should be a key characteristic of federalism. Nevertheless, a functioning system of intergovernmental redistribution is important because it works as an insurance against harmful social political disruptions. However, it should be designed carefully not to operate against competition. Furthermore, fiscal spillovers can be reduced. In Switzerland, economic disparities between the cantons and municipalities are adjusted through such a system of intergovernmental redistribution. First, the federal income tax has redistributive effects because it is designed as a strongly progressive tax. It thus compensates the low progression of some of the cantonal income taxes. Second, the federal government redistributes 13 percent of the total of its income tax between the cantons according to an index of the financial power of the 26 cantons. ${ }^{40}$ The

\footnotetext{
${ }^{38}$ Here, a clear case in point also are very small and economically very successful countries like Luxemburg and Liechtenstein.

${ }^{30}$ Other federally organized states as the United States, Canada, Australia, or Germany show similar tendencies. Nevertheless, Switzerland can be judged as an extreme example, as fiscal federalism is especially marked

${ }^{40}$ The formula for distribution is as follows: Share per Canton in CHF $=2,712828$ (IFC $\left.x-0.0192104\right) x$ (Population/1000) x (SFT/I Million). IFC stands for Index of Fiscal Capacity, SFT for Share of Federal Tax Income for redistribution in CHF. For details see Bundesgesetz 613.1 (19.06.1959) 8, 1 and, for the formula, Bundesverordnung 613.13 (27.11.1989) 1,1
} 
index is reviewed every two years and is composed of four variables: GDP per capita, tax income, tax burden, and the share of mountainous areas in the canton. ${ }^{41}$ The actual system of intergovernmental redistribution was introduced in 1959 and has now grown complicated and intransparent. Consequently, it is currently under reform. The idea is to establish a new assignment of functions, to strengthen the mechanism of unconditioned transfers, and to avoid incentives for the cantons to report their financial power incorrectly. Third and finally, the cantons themselves manage the redistribution among their municipalities based on their financial power.

An important element of the race-to-the-bottom hypothesis is the idea that individuals move to places where they receive more transfers. In Switzerland, a special mechanism for compensating transfers to immigrants from other cantons works against these effects. Transfers to individuals who have recently moved to another jurisdiction are paid by their jurisdiction of origin for a certain time. For example, social welfare assistance is paid by the canton of origin for two years at the rate of the canton of origin. After that, the costs are split half between the canton of origin and of residence over the next eight years. ${ }^{42}$ The amount which the canton of origin has to pay is negotiated by the cantons. Therefore, cantons with high social-welfare assistance have the incentive to deter people with a high possibility of dependency. ${ }^{43}$ Another example can be found in the education system. University can tons receive between CHF 9,500 and 46,000 per year and per student from the canton where students finished school. The rates are defined according to the faculty of enrollment of the student. ${ }^{44}$

Switzerland is well known for its system of representative democracy combined with extensive direct democratic rights for its citizens. ${ }^{45}$ Nine cantons decide on their tax rates in parliament; the other 17 decide on the tax rates in referenda. Thus, voters have influence on the tax burden. Many authors say that direct democracy has stabilizing effects on fiscal federalism. ${ }^{46}$ First, according to Feld, direct democracy is an econometrically significant variable in explaining why high-income individuals do not move away from cantons with a higher tax burden. ${ }^{47}$ Second, Roland Vaubel and others claim that direct democracy works against the natural tendency of a

${ }^{4}$ Swiss Federal Tax Administration (Eidgenōssisches Finanzdepartement), Index der Finanzkraft der Kantone für die Jahre 2000 und 2001, 12 November 2001, htp://www.admin.ch/efv/finanzen/d/intvergl/ intstaq.htm.

42See Bundesgesetz 851.1 (24.06.1977) 16, 1. 133.

${ }^{45}$ See Feld, "Tax Competition and Income Redistribution-An Empirical Analysis for Switzerland,"

${ }^{44}$ See Interkantonale Universitātsvereinbarung 414.23 (20.02.1997) 12, 1

${ }^{45}$ Direct democratic rights on the federal level are: obligatory referenda for changes in the constitution, facultative referenda for certain issues (e.g., foreign policy), and popular initiatives where 100,000 voters can demand constitutional changes. Every canton has its own constitution with its particular set of direct democratic rights. Even municipalities in the same canton can differ in their direct democratic rights.

${ }^{46}$ Another institution counteracting centralization are "sunset laws" concerning the competence of the federal authorities for certain issues. Thus, for example, the existence of the federal value added tax and the federal income tax has to be periodically confirmed by a popular referendum.

${ }^{4}$ 'See Feld, "Exit, Voice and Income Taxes-The Loyalty of Voters," p. 471. 
centralization of fiscal competences in federal states. ${ }^{48}$ Thus, for example, unlike Germany, Switzerland has not experienced a "crawling" centralization and harmonization in the decades since World War II. ${ }^{49}$ Other studies show similar effects for the United States. ${ }^{50}$ Third and finally, direct democracy is said to have a mitigating effect on the absolute level of state activity, Werner W. Pommerehne and Friedrich Schneider note that government size in Swiss cantons with direct, democratically controlled taxes is significantly smaller than in the remaining cantons, and Lars P. Feld and Gebhard Kirchgāssner observe lower debts in jurisdictions with elements of direct democracy in their constitutions. ${ }^{51}$

Competition between jurisdictions in Switzerland can be perceived as a function of the possibilities of "exit" (fiscal federalism) and "voice" (direct democracy). According to Albert O. Hirschman, a "more solid understanding of the conditions favoring coexistence of exit and voice is gained by introducing the concept of loyalty." 52 Loyalty understood as the consequence of a mixture of specific investments in social networks, reputation, and cultural factors (e.g., language) is an important barrier to exit and thus counteracts tendencies toward a race to the bottom. Apart from that, it is conceivable that loyalty has positive effects on the willingness of the better off to pay transfers in smaller jurisdictional units. This may be illustrated by the example of the canton of Geneva. Here the tax burden is relatively high, and direct democratic rights are relatively restricted. Nevertheless, the percentage of people with a high taxable income is sizeable. On the other hand, Michael Wohlgemuth and Ivan Baron Adamovich argue that federal systems as well as direct democracy are conducive to loyalty because the preferences of the voters matter more. This also makes citizens more aware of and more responsible for local issues. If this is so, (fiscal) federalism and loyalty mutually reinforce each other ${ }^{53}$

${ }^{18}$ See Roland Vaubel, Constitutional Safeguards against Centralization in Federal States: An International Cross-Section Analysis (Universitāt Mannheim, Beiträge zur Angewandten Wirtschaftsforschung: Discussion Paper 532-95, 1995); Wohlgemuth and Adamovich, Systemwettbewerb in der Schweiz-Ein Testfall für das Zusammenspiel von "Exit", "Voice" und "Loyalty"; and Eichenberger and Hosp, "Die institutionellen Leitplanken wirkungsvollen Föderalismus-Erfahrungen aus der Schweiz," 87-104. For the natural tendency towards centralization see Bruno S. Frey and Reiner Eichenberger, "To Harmonize Or To CompeteThat's Not The Question," Journal of Public Economics 60 (1996): 335-349. Charles B. Blankart, Politische Ökonomie der Zentralisierung der Staatstätigkeit (Humboldt-Universität zu Berlin: Discussion Paper, Economics Series, 1998), proves this tendency for Germany between 1949 and the 1990s.

${ }^{49}$ Kirchgāssner and Pommerehne, "Die Entwicklung der öffentlichen Finanzen in föderativen Systemen," p. 156

${ }^{50}$ See, for example, John G. Matsusaka, "Fiscal Effects of the Voter Initiative: Evidence from the last 30 Years," Jourmal of Political Economy 10 (3 1995): 587-623.

${ }^{31}$ See Werner W. Pommerehne and Friedrich Schneider, "Unbalanced Growth between Public and Private Sectors: An Empirical Examination," Public Finance and Public Employment, ed. Robert H. Havemann (Detroit: Wayne State University Press, 1982), pp. 309-326; and see Lars P. Feld and Gebhard Kirchgässner, "Public Debt and Budgetary Procedures: Top Down or Bottom Up? Some Evidence from Swiss Municipalities," Volkswirtschaftliche Abteilung (Universität St. Gallen: Discussion Paper Nr.9717, 1997).

${ }^{32}$ Albert O. Hirschman, Exit, Voice and Loyalty (Cambridge, MA: Harvard University Press, 1970), p. 77 emphasized by the author. In the terminology of Douglass $\mathrm{C}$. North "loyalty" is an informal institution as opposed to the formal laws we have treated up to now: Douglass C. North, "Institutions," Journal of Economic Perspectives 5 (1 1991): 97-112.

${ }^{53}$ See Michael Wohlgemuth and Ivan Baron Adamovich, Systemwettbewerb in der Schweiz-Ein Testfall für das Zusammenspiel von "Exit", "Voice" und "Loyalty". Bruno S. Frey and Alois Stutzer, "Maximizing Happiness?" German Economic Review 1 (1999): 145-167, have even found for Switzerland, that federalism and direct democracy improve the happiness of people. 
Of course, Switzerland is no "utopia." In summary, however, the country seems to have produced an interesting institutional setting combining elements of exit, voice, and loyalty conducive to interjurisdictional competition. According to standard indicators (e.g., per capita income) and in the sense of comparative institutional analysis, Swiss federalism can be regarded as a long-term success, even compared to its European neighbors. Naturally, this does not mean that a simple export of the Swiss system of fiscal federalism will have the same positive effects in other countries. A careful analysis of the institutional setting has to be undertaken. The next part will take some first steps in this direction.

\section{FISCAL FEDERALISM IN LATIN AMERICA?}

Many countries in Latin America, such as Argentina, Brazil, Colombia, Bolivia, Mexico, and Venezuela, are decentralizing and increasing democratic rights and responsibilities in the provision of public services. For example, Gabriel Aghón and Ernesto Stein stress a trend toward decentralization. ${ }^{54}$ Between 1985 and 1995, the degree of decentralization in public expenditures increased by 4 percent in 14 Latin American countries. However, in comparison to the OECD countries, Latin America is highly centralized. In 1995 , less than 15 percent of total government expenditures were executed by subnational governments, on average, in Latin America. The corresponding figure in industrialized countries is over 35 percent. $^{55}$ Only Argentina, Brazil, and Colombia exceed the OECD average. Even so, of course, the mere degree of decentralization does not tell us anything about the quality of the institutional setting and the intensity of interjurisdictional competition.

To be able to see whether the Swiss experience bears lessons for the design of fiscal federalism in emerging economies in Latin America, we examine whether the formal and informal institutions identified previously are present in Latin American countries. Because of their importance in the region, we take a closer look at Brazil and Argentina. In a second step, we examine a group of typical institutional arrangements in emerging economies (e.g., important differences in regional income, informal economy, and corruption) as to their effects on fiscal federalism.

\section{Coordinated Fiscal Federalism in Latin America}

The institutions discussed previously mainly have one effect: to dampen the negative effects of tax competition without abolishing the competition between jurisdictions. As noted earlier, tax competition produces constraints for politicians that result in a better package of taxes and public services.

${ }^{34}$ See Gabriel Aghón, Decentralización fiscal en América Latina: balance y principales desafios (Documento preparado para la Reunión de LASA, 1997, Mimeo) and Ernesto Stein, "Fiscal Decentralization and Government Size in Latin America," Joumal of Applied Economics Il (2 1999): 357.391.

${ }^{55}$ The figures mentioned in this part are based on Stein, "Fiscal Decentralization and Government Size in Latin America." 
Competition also is expected to create incentives and better possibilities for innovation in the political sphere. Scholars like Musgrave and others emphasize the role of cooperation and coordination in a federal system in order to avoid the supposed race to the bottom. ${ }^{56}$ It seems that the federal systems in the more decentralized countries of Latin America have been designed along these lines. Ernesto Rezk, for example, emphasizes that in Argentina, the aspect of coordination has prevailed over the idea of interjurisdictional competition: "Revenue sharing was the preferred method of tax coordination in the country, coparticipation becoming 'the' intergovernmental fiscal arrangement, whereby national and subnational levels sought to avoid tax competition among jurisdictions." 57

Ricardo Varsano describes the most prominent case of tax competition in Latin America, the state value-added tax in Brazil (ICMS), as a "fiscal war." This bad connotation underlines apparently existing reservations against tax competition. ${ }^{58}$ Varsano even notes: "Virtually all recent work on tax competition in federations concludes that the last-named practice is pernicious." 59

In any case, the literature on federalism in Latin America seems to focus mainly on the idea of federalism as some kind of cooperative or coordinated decentralization. ${ }^{60}$ Consequently, inter-and intragovernmental redistribution are perceived to be crucial for making federalism work. Generally, transfers can be allocated by discretion or legal requirements. As Stein reports, a third of the transfers in Latin America are discretionary ${ }^{61}$ According to Inman and Rubinfeld and to Stein, discretion and negotiation raise serious problems in comparison to a rule-based approach. ${ }^{62}$ For example, they doubt that interjurisdictional Coasian bargains are effective, and they describe the negative incentives for federal subunits. If programs of subnational jurisdictions are not solely financed with their own revenues, there is a tendency to overexpand the budget and to require more transfers from the

${ }^{56}$ See Richard A. Musgrave, "Devolution, Grants, and Fiscal Competition," Joumal of Economic Perspectives 11 (4 1997): 65-72,

${ }^{57}$ Emesto Rezk, "Recent Developments on Federalism and Decentralization: Lessons from the Argentine Experience," Paper presented at the Conference on Fiscal Decentralization, IMF Headquarters (Washington, DC: November 2000, Mimeo), p. 4.

${ }^{58}$ The more relevant question seems to be, if value-added taxes are an adequate vehicle for tax competition.

${ }^{59}$ Ricardo Varsano, "Brazil: tax reform and the "fiscal war" in the federation," Federations l (March 2001).

${ }^{\infty}$ See Inman and Rubinfeld, "Rethinking Federalism." They distinguish between "cooperative" and "democratic" federalism. As opposed to cooperative federalism, in the democratic version decisions are taken by the majority and not unanimously. This article does not make this difference and only uses the term cooperative federalism.

${ }^{61}$ Stein, "Fiscal Decentralization and Government Size in Latin America," 373.

${ }^{62}$ See Inman and Rubinfeld, "Rethinking Federalism," and Stein, "Fiscal Decentralization and Government Size in Latin America." Also see Mariano Tommasi, Sebastián Saiegh, and Pablo Sanguinetti, "Fiscal Federalism in Argentina: Policies, Politics, and Institutional Reform," Economia 1 (2 2001): 147 . 190. They provide a political-transactions theory, which shows the trade off between rigid rules and discretional responses. For a closer look to less developed countries see Roy Bahl and Johannes Linn, "Fiscal Decentralization and Intergovernmental Transfers in Less Developed Countries," Publius: The Journal of Federalism 24 (Winter 1994): 1-19. 
common pool; this is the well-known tragedy of the commons. Finally, discretionary redistribution bears a high potential for political and not economic considerations in governmental decisions on revenues. This means that the political bargaining skills of local politicians become more important than management skills.

In spite of Argentina normally being perceived as a rule-based federal state, Sebastián Saiegh and Mariano Tommasi provide a list of important criticisms regarding the tax-sharing agreement. The problems here are very similar to the problems of discretionary regimes. Among others, Saiegh and Tommasi criticize the existence of bailouts, induced inefficiencies in the aggregate fiscal mix, a lack of incentives for federal subunits to produce information, and the high complexity of the system. According to the authors, political instability and institutional rigidities are the main reasons for the inefficiency of Argentina's intergovernmental redistribution. Politically, the Argentinean tax-sharing agreement can be interpreted as a veto-game because the laws require ratification by provincial legislatures. ${ }^{63}$ Also, in Brazil, a considerable share of transfers is constitutionally mandated, but there are some discretionary and negotiated transfers too. This makes Brazil's system complicated and intransparent. In any case, José R.R. Afonso and Luiz de Mello call for more (and not less) coordinated federalism in order to avoid financing shortfalls at the subnational level. ${ }^{64}$

Another issue frequently discussed in the literature is the way intergovernmental grants and transfers should be determined. Thus, it is expected that an unconditioned redistribution allows the authorities in federal subunits to spend the financial means according to the preferences of the people, provided the political control of the authorities works. ${ }^{65}$ Although transfers in Argentina and Brazil are mostly unconditional, a mixed system of delegation, earmarked grants and revenues, and forced and unforced coparticipation have helped to build a fiscal "labyrinth" with mutual dependencies. ${ }^{66}$ The example of Brazil shows possible harmful effects of the earmarking of sharable revenues by the federal government. There, the federal government has to share the revenues of the income tax and the federal value-added tax with the subnational jurisdictions. This has led to an increase of the enterprise payroll and earnings taxes, which are not earmarked for sharing, with distortional effects in the labor market and for the international competitiveness of the country. ${ }^{67}$

In Latin America, the aim of the interjurisdictional redistribution is to produce a system of coordinated federalism. Because of this, redistribution

${ }^{63}$ See Sebastián Saiegh and Mariano Tommasi, Why is Argentina 's Fiscal Federalism so Inefficient? Entering the Labyrinth (Paper prepared for the "Conference on Modernization and Institutional Development in Argentina", PNUD, Buenos Aires, 20-21 May 1998, Mimeo), p. 9.

${ }^{G-4}$ See José R.R. Afonso and Luiz de Mello, "Brazil: An Evolving Federation," Paper presented at the Conference on Fiscal Decentralization, IMF Headquarters (Washington, DC: November 2000, Mimeo), p. 21. ${ }_{65}^{65}$ For a different point of view see Richard A. Musgrave, "Devolution, Grants, and Fiscal Competition," Joumal of Economic Perspectives 11 (4 1997): 65-72.

${ }^{6}$ See Saiegh and Tommasi, Why is Argentina's Fiscal Federalism so Inefficient? Entering the Labyrinth, p. 8. ${ }^{67}$ See Afonso and de Mello, "Brazil: An Evolving Federation," p. 7. 
produces wrong incentives and leads to a severe common-pool problem and bailout scenarios. As opposed to this, Swiss federalism is focused more on competition and fiscal equivalence; grants and transfers are understood as means to equalize the financial power of federal subunits without abolishing the benefits of competition. In this context, the current taxrevenue sharing design in Switzerland is regarded as being far from perfect, but the actual reforms are expected to take a further step into encouraging fiscal discipline and responsibility.

To our knowledge, the Swiss mechanism for compensating transfers to immigrants from other federal subunits is not matched by any comparable institution in Latin America. Above all, this seems to be a question of institutional innovation. A reason for these innovations not happening could be either a lack of knowledge or (more probably) a question of political enforceability (technically speaking, of a politico-economical equilibrium). Other institutions like competitive federalism or directdemocratic elements could help to improve the ability for innovation. On the other hand, a mechanism like the above can only operate under certain administrative preconditions that allow governments to track the movements of citizens (e.g., registration of citizens and a national identity card).

Another institution supporting the functioning of fiscal federalism is direct democracy. Since 1848, Switzerland has experienced 466 referenda and initiatives at the federal level, not counting the innumerable plebiscites in cantons and localities. The first reported referendum in Latin America was held on the provisional constitution in 1812 in Chile. Since then, 88 popular votes were counted in the whole of Latin America, mainly at the federal level. ${ }^{68}$ Recently, first signs of the introduction of more direct democracy in Latin America can be noticed; the Province of Buenos Aires established forms of direct democracy in $1994 .^{69}$ Direct democracy is said to give the politicians incentives for credible commitment to policies. Especially in the subnational jurisdictions, it is supposed to lead to a better control of the officials. It could be argued that as direct democracy has a long tradition in Switzerland, the Swiss experience cannot be taken as an example for other societies. Nevertheless, every tradition has a starting point. Although this form of democracy does not have much tradition in Latin America, citizens seem to have learned to deal with it where it was introduced. However, people in Latin America learn to use their democratic rights. Alberto Porto and Natalia Porto report that voters in municipal elections in Argentina are sensitive to the fiscal performance of the relevant municipal authority in the recent past. ${ }^{70}$ Nevertheless, Latin America's still relatively young democracies have to prove to be stable. According to Marta

${ }^{68}$ See Research and Documentation Centre on Direct Democracy, South America: Regional votes up to today, 12 November 2001; http://c2d.unige.ch.

${ }^{69}$ See AJberto Porto and Natalia Porto, "Fiscal Decentralization and Voters' Choices as Control," Journal of Applied Economics III (1 2000): 157.

7olbid., 135-167. 
Lagos from "Latinobarometro," an average of 20 percent of the individuals asked in South America and Mexico would support an authoritarian government "in certain situations" as opposed to an average of 7 percent in the European Union. ${ }^{71}$

Last but not least, the rural exodus toward the big cities in most if not all Latin American countries indicates that loyalty does not have the same intensity and/or effects as in Switzerland. Perhaps the bigger regional economic disparities in most parts of Latin America are an important factor. It can be expected that the opportunity costs of staying in poorer areas rise with bigger gaps in welfare between different locations. Also, as Hirschman said, loyalty is only a "postponement of exit in spite of dissatisfaction and qualms." 72 Of course, there is a point where the expected individual gains from migrating are higher than the benefits from loyalty. Another reason could be that Switzerland features more cultural and language differences than Latin American countries. It seems that loyalty can be enhanced (among other things) by the formation of social capital, which has been identified as substantial for economic relations, especially in developing countries. ${ }^{73}$ Lagos identifies a lack of interpersonal trust, which is a prerequisite for the accumulation of social capital. ${ }^{74}$

To conclude this section, we remark that the main trend at the core of decentralization in Latin America is one toward coordination. This may be contrasted with the elements of interjurisdictional competition that are taken to be at the heart of fiscal federalism in Switzerland. This is where the main positive effects of decentralization can be expected to arise. The numerous skeptics of fiscal federalism are probably also influenced by the poor record of coordinated federalism. Interestingly, the opponents do not call for more competition but for recentralization. ${ }^{75}$

\section{Challenges to Introducing Competitive Federalism}

In addition to the problem of avoiding a race to the bottom, the introduction of competitive fiscal federalism in emerging economies is loaded with challenges. Four issues seem worth discussing: (1) the challenge of preserving the internal markets; (2) important regional differences; (3) the big informal economy compared to industrialized countries; and (4) corruption.

A severe challenge to decentralization is the maintenance of the internal markets. In this context, the literature speaks of market-preserving federalism. For sustaining an efficient market economy, decentralized

${ }^{7}$ Marta Lagos, "Between Stability and Crisis in Latin America," Joumal of Democracy 12 (1 2001): 138

${ }^{72}$ Hirschman, Exit, Voice and Loyalty, p. 104. As an anonymous referee has rightly pointed out to us, loyalty may also be influenced by geographical and climatic factors. Someone may be reluctant to leave a high tax/low service community at the lake of Geneva for a low tax/high service community in the snowy and mountainous canton of Uri.

${ }^{73}$ See Kurt Annen, "Inclusive and Exclusive Social Capital in the Small-Firm Sector in Developing Countries," Joumal of Institutional and Theoretical Economics 157 (2 2001): 319-330.

${ }^{74}$ See Lagos, "Between Stability and Crisis in Latin America," 137-145.

${ }^{75}$ See, for example, Tanzi, Pitfalls on the Road to Fiscal Decentralization. 
governments should face hard-budget constraints and have the regulatory responsibility for the economy. ${ }^{76}$ There should be no barriers to trade. The value-added tax levied by the federal subunits in Brazil is said to encourage tax warfare and to impede trade between them. Nevertheless, according to the ideas of market-preserving federalism, this kind of competition is not necessarily harmful as long as the states get enough revenue. In particular, if budget constraints are hard and states cannot rely on a bail out from the federal government, they are forced to manage their budgets more carefully. Hard budget-constraints also have other positive effects; the federal subunits will have to be more careful when they grant subsidies to attract firms and individuals. ${ }^{77}$ In general, the concept of market-preserving federalism seems to neglect the role of a central authority as guardian of competition enforcing general rules for the subnational jurisdictions.

Countries with strong regional disparities may suffer from centrifugal forces leading to separatist movements. Of course, regional differences are one reason for fiscal federalism where a uniform provision of public services is not perceived to be optimal. However, large differences in income levels exist in emerging countries. Some subnational governments can be too poor to provide a minimum of public services. Therefore, interjurisdictional redistribution plays a crucial role in fiscal federalism.

Tax evasion and a huge informal economy are other challenges. Friedrich Schneider and Dominik H. Enste report that the size of the shadow economy in developing countries is systematically larger than in the OECD countries. In Japan, the United States, Austria, and Switzerland, the shadow economy is estimated to amount to 8-10 percent of GDP. With 25-35 percent of GDP, Colombia, Brazil, Venezuela, and Chile have bigger shadow economies. Mexico's and Peru's shares are even estimated to be between 40-60 percent. ${ }^{78}$ A low tax compliance and high tax evasion can undermine the ability of federal subunits to raise revenues. To solve this problem, an improvement of tax administration is often advocated. Vito Tanzi expects that there are economies of scale in tax administration and, consequently, wants taxation to be centralized. ${ }^{79}$ On the other hand, there seem to be no obstacles for federal subunits to buy services from a central tax administration. In Switzerland, it even is the other way around; the cantonal tax administrations collect the federal income tax. The power to tax and not the actual collection of taxes is crucial. Another way to increase the effectiveness of taxation could be to expand political participation. For

${ }^{76}$ See Quian and Weingast, "Federalism as a Commitment to Preserving Market Incentives," 83-92 and Oates, "An Essay on Fiscal Federalism," 1120-1149.

${ }^{77} \mathrm{~A}$ characteristic of coordinated federalism seems to be a competition between the states of who grants higher subsidies (obtained from the federal authorities) to attract firms.

${ }^{7}$ See Friedrich Schneider and Dominik H. Enste, "Shadow Economics: Size, Causes, Consequences," Journal of Economic Literature XXXVIII (March 2000): 80. The size of the shadow economy is measured a percent of GDP, averaged over 1990-1993. Also see Varsano, "Brazil: tax reform and the "fiscal war" in the federation."

${ }^{7}$ See Tanzi, Pitfalls on the Road to Fiscal Decentralization. 
example, Werner W. Pommerehne et al. show that tax evasion is lower under the regime of direct democracy. ${ }^{80}$

The last challenge to discuss is corruption. According to Tanzi, local institutions are less developed than national ones, especially in poor countries. The best and most talented people join the national government. $^{81}$ In some regard, this statement is a self-fulfilling prophecy. If the possibilities and responsibilities of subnational governments are not strengthened, then local institutions cannot be attractive employers. In addition, even centralized countries consist of several levels of administration. The question is, which system offers more discretionary power for the officials? It can also be argued that political control matters. If the people in subnational units can exercise democratic rights, abuse of power will be more difficult than under a pure bureaucratic hierarchy. The final judgement depends on how one values the principal-agent relationship between the national government and local authorities on one side and local authorities and voters on the other side.

\section{POLICY CONCLUSIONS}

It seems fair to say that fiscal decentralization in Switzerland works as a mechanism for controlling and constraining politicians and thus producing political outcomes better matched to peoples' preferences. Evidence can also be found that fiscal federalism is an important reason for the efficiency of politics and maybe even for the relative economic success of Switzerland.

As the analysis has shown, the Swiss experience provides us with a group of important institutional arrangements working as preconditions for mitigating or even averting the potentially negative effects of competitive federalism. In particular, we have recognized intergovernmental redistribution, interjurisdictional compensation mechanisms, elements of direct democracy, and loyalty to be crucial for making federalism work. Of course, this enumeration is not necessarily complete. For example, the literature also stresses such elements as the power to tax and the assignment of functions. Last but not least, it seems important that competition should operate not only between states (cantons) but also between municipalities.

The central feature of the ongoing decentralization in Latin America, however, seems to be cooperation and coordination. The relatively poor record of this kind of federalism has produced a great number of critics of fiscal federalism in general. Differing from those skeptics, in our view the most important flaw of decentralization in Latin America is the lack of interjurisdictional competition. In addition to the problem of avoiding a race to the bottom, there is a group of serious challenges for introducing a

\footnotetext{
${ }^{80}$ See Werner W. Pommerehne, Albert Hart, and Bruno S. Frey, "Tax Morale, Tax Evasion, and the Choice of Tax Policy Instruments in Different Political Systems," Supplement to Public Finance/Finance Publique 49 (1994): 52-69.

${ }^{81}$ See Tanzi, Pitfalls on the Road to Fistal Decentralization.
} 
properly working system of competitive fiscal federalism in emerging economies. This generalization seems to be adequate in spite of the fact that every country has its own institutional peculiarities.

According to von Hayek, institutions are only partly the results of human design. ${ }^{82}$ Consequently, we always have to take path-dependencies into account when proffering policy advice. Even so, the challenges to the introduction of competitive fiscal federalism are not a reason to abolish the idea. The empirical and theoretical evidence for positive effects seems to be too clear. Still, as we have said above, one has to be careful with advocating a simple "transplant" of the Swiss institutional system to emerging economies. Especially the "export" of the concept of direct democracy faces serious problems. Nevertheless, even minor steps toward democratization, particularly in the realm of tax autonomy, could strengthen fiscal competition in Latin America. Last but not least, the Swiss systems of redistribution and interjurisdictional compensation seem to be relatively simple institutional arrangements that can be transferred easily to other countries. In this case, the major problem seems to be the political feasibility in the different countries concerned. In any case, it is surely worth taking the Swiss experience seriously; it is probably one of the most interesting and successful laboratories for the working properties of fiscal federalism in the world.

${ }^{82}$ See Friedrich A. von Hayek, "The Confusion of Language in Political Thought," New Studies in Philosophy, Politics and Economics, ed. Friedrich A. von Hayek (Chicago: University of Chicago Press, 1978), pp. 71-97. 
